удК 343.9

DOI https://doi.org/10.32837/apdp.v0i88.3050

І. В. Берднік, М.Б. Головко

\title{
ФУНКЦІОНАЛЬНІ ОСОБЛИВОСТІ ЛЮДИНИ ЯК СКЛАДНИК ОПЕРАТИВНО- РОЗШУКОВОЇ ХАРАКТЕРИСТИКИ КРИМІНАЛЬНИХ ПРАВОПОРУШЕНЬ
}

Постановка проблеми. В теорії оперативно-розшукової діяльності всі злочинні діяння характеризуються в рамках такого поняття, як «оперативно-розшукова характеристика кримінальних правопорушень». До теорії та практики оперативно-розшукової діяльності (далі - ОРД) це поняття було введено на перетині 70 -х 80-х років XX століття. Однак єдиної думки про його зміст до теперішнього часу не вироблено з огляду на існування різних наукових підходів щодо його дефініції, сутності й змістовних елементів.

Аналіз останніх досліджень і публікацій. Питання дослідження проблемних аспектів функціональних особливостей людини досліджувались у працях В.І. Барка, Ю.Б. Ірхіна, І.М. Комарова, Г.О. Овчиннікова, В.М. Чулахова тощо.

Метою цієї статті є аналіз функціональних особливостей людини як складник оперативно-розшукової характеристики кримінальних правопорушень.

Виклад основного матеріалу дослідження. Вважається, що як самостійні елементи наукові положення оперативно-розшукової діяльності були сформовані на підставі понятійного апарату кримінального права, криміналістики та кримінології. Отже, оскільки молода наука ОРД стикнулася з необхідністю вивчення все того ж явища - кримінального правопорушення, перед науковцями постало завдання сформулювати свою дефініцію щодо досліджуваного об'єкта. Результатом його розв'язання стало поняття «оперативно-розшукова характеристика кримінальних правопорушень», елементи якого, на думку більшості науковців, дублюють складники насамперед криміналістичної характеристики. Це пов'язано 3 тим, що основною метою як оперативно-розшукової діяльності, так і криміналістики є розкриття злочину [1, с. 67]. Проте самостійне наукове значення цього поняття передбачає наявність у його змісті специфічних для науки елементів.

Аналіз наявних визначень оперативно-розшукової характеристики злочинів (кримінальних правопорушень) свідчить про їі розгляд науковцями як певної інформаційної парадигми [2, с. 8889], системи (сукупності) найбільш істотних, узагальнених (загальних) ознак і властивостей окремого виду (групи) загальнонебезпечних діянь, визначених з метою вирішення завдань оперативно-розшукової діяльності [1, с. 68-69; 3, с. 110], для розробки оперативно-розшукових версій, методик виявлення, попередження, припинення і розкриття злочинів, за допомогою застосування відповідних сил, засобів, а також специфічних для цієї діяльності методів. Завдяки теоретичній (науковій) моделі оперативно-розшукової характеристики кримінальних правопорушень певного виду оперативний працівник має можливість визначити джерела інформації про конкретний вид злочину з метою iï подальшого використання у виявленні, попередженні, припиненні і розкритті

(C) І. В. Берднік, М. Б. Головко, 2020 
злочинів, а також під час встановлення осіб, що їх готують, вчиняють чи вчинили. Знання загальноправової, кримінологічної та криміналістичної характеристик окремого виду кримінальних правопорушень дозволяє не тільки оптимізувати процес розкриття та розслідування, але й за певних умов досягти їх попередження.

Сполучною ланкою комплексу ознак оперативно-розшукової характеристики певного виду кримінальних правопорушень має виступати агентурно-оперативний складник, оскільки під час здійснення ОРД в основному застосовуються негласні форми і методи, які не враховують вищезазначені науки, а тому окремі елементи кримінального правопорушення саме з позиції застосування негласних форм і методів вони не розглядають. Усунути цю прогалину покликана оперативно-розшукова характеристика кримінальних правопорушень певного виду, складовим елементом якої повинна бути інформація оперативно-розшукового характеру.

Принципово визначальним, якісним параметром оперативно-розшукової характеристики кримінальних правопорушень науковці визначають негласну діяльність як «специфіку доступності злочинів і в цілому кримінальних структур для впровадження конфідентів і використання інших джерел оперативно-розшукової інформації» [4, с. 31].

Не заглиблюючись у проблематику різноманітності дефініцій, стислий аналіз наукових підходів дає підстави виділити такі основні елементи, що дозволяють отримати найбільш повне уявлення про оперативно-розшукову характеристику кримінальних правопорушень:

1. Характер вчиненого діяння, що підпадає під ознаки кримінального правопорушення.

2. Способи його здійснення (способи приховування).

3. Характеристика особи, що готується вчинити (вчинила) кримінальне правопорушення чи ухиляється від органів досудового розслідування, слідчого судді, суду або від відбування кримінального покарання.

4. Характеристика особи жертви кримінального правопорушення.

5. Доступність для оперативного впровадження з метою виконання завдань ОРД.

3 урахуванням специфіки предмета дослідження видається за можливе визначити оперативно-розшукову характеристику кримінальних правопорушень як інформаційну модель, що складається з сукупності окремих аспектів кримінально-правової, криміналістичної, кримінологічної, психологічної, віктимологічної характеристик, урахування яких в оперативно-розшуковій діяльності забезпечує найбільш ефективне планування і здійснення оперативно-розшукових заходів по виконанню визначених законодавством завдань ОРД.

Окремої уваги в контексті нашого дослідження заслуговують елементи, що характеризують особу, яка вчинила кримінальне правопорушення, зокрема, їі певні навички та функціональні особливості, що зумовлюють передкримінальну поведінку особи, вчинення нею кримінального правопорушення та її посткримінальну поведінку.

Встановлення особи, яка вчинила злочин або будь-яким чином причетна до його вчинення, є одним зі складних і відповідальних завдань на всіх етапах як ОРД, так і досудового розслідування. 
Основними, значущими для застосування у процесі здійснення ОРД ознаками людини як джерела інформації, є:

1) індивідуальний характер. Як і будь-який об’єкт ідентифікації, людина має ознаки неповторності та відмінності від інших матеріальних та ідеальних об'єктів;

2) наявність комплексу соціально-психологічних властивостей;

3) сукупність генетично певних факторів, що лежать в основі функціонування людини як біосоціальної системи, мають свій виявив у соматичних, морфологічних і психічних властивостях особистості;

4) участь у процесах відображення властивостей особистості людини у процесі вчинення нею злочину;

5) феноменальний характер, сутність якого в синетичному дослідженні людини, виходячи з позицій різних наук [5, с. 216].

Часто трапляються такі ситуації, коли злочинцеві вдається втекти з місця події, і про нього недостатньо інформації або вона зовсім відсутня. У подібних випадках діяльність правоохоронних органів щодо встановлення особи складається з двох стадій: виявлення особи шляхом збирання інформації, що вказує на особу як таку, що могла вчинити злочин, і викриття злочинця, тобто збирання фактичних даних, що є достатніми для висновку щодо вчинення цього злочину конкретною особою [6, с. 17].

У процесі проведення ОРД досягнення зазначених завдань забезпечується шляхом застосування окремих заходів, визначених ч.1 ст.8 закону України «Про оперативно-розшукову діяльність», чи комплексного їх використання.

В епоху глобальної комп'ютеризації суспільства кримінальні правопорушення все частіше вчиняються 3 використанням інформаційно-телекомунікаційних мереж: це і окремі злочини проти життя і здоров'я (доведення до самогубства або схиляння до його вчинення), і проти статевої свободи та недоторканості (розбещення неповнолітніх), і проти власності (крадіжки, шахрайства).

3 огляду на те, що в результаті вчинення зазначених злочинів можуть залишатися так звані «віртуальні» сліди, як окремий напрям щодо встановлення у процесі проведення ОРД особи злочинця можна виділити використання різних інформаційно-телекомунікаційних мереж (у тому числі й мережу Інтернет).

Так, реалізуючи досягнення сучасної криміналістичної техніки, можливо, наприклад, своєчасно виявляти осіб, які займаються закликами і агітацією здійснення суїцидів неповнолітніми [6, с. 96]:

- виявлення «груп смерті», заборонених сайтів та інших соціальних груп, які схиляють неповнолітніх до вчинення суїцидів;

- встановлення особи адміністраторів сайтів, які повинні вживати заходів до видалення інформації, що завдає шкоди здоров'ю і розвитку дітей;

- встановлення особи людини, що займається пропагандою і закликами до здійснення суїцидів. Для цього необхідно вилучити телефони, комп'ютери та іншу техніку як самого потерпілого, так і осіб, з якими він спілкувався.

Зазначені завдання можуть бути вирішені під час проведення судових комп'ютерно-технічних досліджень, а також, зокрема, таких оперативно-розшукових заходів (далі - ОРЗ), як: негласне виявлення та фіксація слідів тяжкого або 
особливо тяжкого злочину, документів та інших предметів, що можуть бути доказами підготовки або вчинення такого злочину, у тому числі шляхом проникнення та обстеження публічно недоступних місць, житла чи іншого володіння особи; виконання спеціального завдання з розкриття злочинної діяльності організованої групи чи злочинної організації; здійснення аудіо-, відеоконтролю особи, зняття інформації з транспортних телекомунікаційних мереж, електронних інформаційних мереж; здійснення спостереження за особою, річчю або місцем, а також аудіо-, відеоконтроль місця; використання конфіденційного співробітництва. Зазначені ОРЗ проводяться в порядку та на підставах, визначених законом «Про оперативно-розшукову діяльність» та Кримінальним процесуальним кодексом України (далі - КПК) [7; 8].

В оперативно-розшуковій практиці для встановлення особи злочинця також використовуються фізичні та анатомічні особливості людського тіла 3 певними властивостями, такими як індивідуальність, рефлекторність і відносна стійкість. При цьому використовуються вихідні положення загальної та оперативної психології, теорії криміналістичної ідентифікації і діагностики та габітоскопія як вчення про зовнішній вигляд людини.

На підставі різних думок дослідників цієї проблеми $[4 ; 5 ; 6 ; 10]$ можна зробити висновок про те, що під час встановлення особистості вивчаються її фізіологічні властивості, які розглядається в практиці ОРД в повній взаємозумовленості і взаємодії загальнофізичних, функціональних, анатомічних, психологічних і супутніх елементів.

Людину індивідуалізують не тільки анатомічні елементи зовнішності, але й особливості функціональних (міміка, хода, жестикуляція тощо) і супутніх елементів (прикраси, предмети одягу, взуття та інші речі, які використовує людина). Ці ознаки можуть бути відображені на записах відеофіксуючої апаратури, що розміщена у громадських місцях (метрополітен, вокзали, автомобільні шляхи, кафе, ресторани). Звідси витікає завдання оперативних співробітників виявити такі носії інформації та у встановленому законом порядку здійснити їх вилучення й дослідження (огляд). На жаль, часто відеозаписи, що підлягають дослідженню, характеризуються низькою якістю, в результаті чого неможливо виявити більшість ознак анатомічних елементів зовнішності, щоб вирішити питання про тотожність. Проте вони можуть відображати деякі функціональні й супутні ознаки, що мають високий ступінь інформативності, завдяки чому можливо ідентифікувати людину і встановити ії особистість (хода, міміка, жестикуляція, одяг, аксесуари тощо).

Поряд 3 тим, як стверджує В.Н. Чулахов, разом з елементами зовнішності, кожна людина виділяється особливостями скоєних нею дій з огляду на сформовані протягом життя навички, які можуть проявлятися під час ходьби, бігу, виготовлення будь-яких предметів, у поведінці тощо [9, с. 3].

Криміналісти відносять навички до особливої групи функціональних елементів, що іноді називають манерами, під якими слід розуміти дії, що здійснюються людиною в зв'язку з задоволенням будь-яких побутових потреб (наприклад, звички, пов'язані з курінням, носінням одягу тощо) [6, с. 37]. 
Український юридичний термінологічний словник визначає навички як уміння, що внаслідок численних повторень стають автоматичними і виконуються без свідомого контролю [10].

Для оперативних працівників володіння методами візуальної психодіагностики стійких функціональних особистісних особливостей належить до розряду найнеобхідніших, що зумовлено специфікою виконання ними завдань ОРД.

Візуальна психодіагностика - визначення істинного (що відображається на невербальному рівні), а не показного (що умисно демонструється на вербальному рівні) психічного стану особи, що становить оперативний інтерес [11, с. 25].

Складання психологічного портрета злочинця за певними навичками і звичками, що виявляються під час вчинення кримінального правопорушення, має велике значення для ОРД. За його допомогою збільшується обсяг і поліпшується якість вихідної інформації, необхідної для встановлення особи злочинця на початкових етапах виявлення кримінального правопорушення.

Під час опису функціональних особливостей потрібно вказати: вид рухів, дій (наприклад, користування носовою хусткою, зубочисткою тощо); найменування анатомічних або супутніх елементів зовнішності, щодо яких здійснюється рух (наприклад, згладжування волосся, розгладження складок одягу тощо); вираженість цих рухів.

3 огляду на специфіку поведінки особи визначення їі функціональних особливостей та навичок слід зазначити, що одним з важливих компонентів ефективного виконання завдань ОРД є використання візуальної діагностики:

- стійких особистісних властивостей (навичок);

- невербальної поведінки осіб, які є об'єктом зацікавленості оперативно-розшукових підрозділів.

До першої групи в теорії психологічного забезпечення ОРД відносять візуальну психологічну діагностику за гендерними відмінностями, за статурою, за зовнішнім виглядом, за ознаками стигматизації характеру, за ознаками віросповідування. До другої - візуальну діагностику ходи, статистичного положення тіла, жестів, міміки, мимовільних реакцій, фонового настрою, нещирості, реакцій на психотравму, психічних патологій [11, с. 27].

Висновки. Таким чином, дослідження й вивчення навичок і функціональних особливостей людини служить основою для висунення версій про особу, яка вчинила кримінальне правопорушення або іншим чином причетна до його вчинення, що дозволить істотно звузити коло розшуку осіб або об'єднати в одне провадження кримінальні провадження про злочини, що мають ознаки серійності. Звісно, під час формування висновку щодо причетності особи до вчинення кримінального правопорушення на підставі дослідження їі навичок та функціональних особливостей має враховуватися сукупність інформації, отриманої під час комплексного проведення оперативно-розшукових заходів, складання психологічного портрета, перевірки за базами оперативних та криміналістичних обліків, провадження експертних досліджень. Цей висновок підлягає перевірці у процесі досудового розслідування шляхом проведення слідчих дій. 


\section{Jimepamypa}

1. Свистильников А.Б. Оперативно-розыскная характеристика террористического акта: проблемы понятия и сущности. Проблемы правоохранительной деятельности. 2014. № 3. С. 64-71.

2. Кондратьев М.В. Оперативно-розыскная характеристика преступлений: к описанию понятия. Исторические, философские, политические и юридические науки, культурология и искусствоведение. Вопросы теории и практики. 2012. № 5-1. С. 88-90. URL: http://elibrary.ru/download/59949014. pdf (дата обращения: 10.11.2020).

3. Насыров Р.Р. Оперативно-розыскная характеристика преступления: проблема содержания. Вестник Владимирского юридического института. 2012. № 3. С. 108-110.

4. Овчинников Г.А. Оперативно-розыскное противодействие преступлениям, совершаемым в сфере потребительского рынка : дис. ... канд. юрид. наук. СПб., 2001. 197 с.

5. Фойгель Е.И. Современный структурно-методический подход к криминалистическому учению о человеке. Российский журнал правовых исследований. 2016. № 3(8). С. 212-218.

6. Самойлов Г.А. Основы криминалистического учения о навыках. Москва, 1968. 119 с.

7. Про оперативно-розшукову діяльність: Закон України від 18 лютого 1992 р. № 2135-XII / Верховна Рада України. URL: https://zakon.rada.gov.ua/laws/show/2135-12\#Tеxt (дата звернення: 10.11.2020).

8. Кримінальний процесуальний кодекс України: Закон України від 13 квітня 2012 р. № 4651-VI / Верховна Рада України. URL: https://zakon.rada.gov.ua/laws/show/4651-17?find=1\&text=\% D0\% B4\% D0 \% BE \% D0\% BF\% D0\% B8\% D1\% 82\#w1_21 (дата звернення: 30.10.2020).

9. Український юридичний термінологічний словник. URL: https://www. org.ua/document/ termin/index.php (дата звернення: 10.11.2020).

10. Чулахов В.Н. Криминалистическое учение о навыках и привычках человека. Москва, 2007. 285 c.

11. Барко В.І., Ірхін Ю.Б. та ін. Психологічне супроводження оперативно-розшукової діяльності органів внутрішніх справ: навчальний посібник. Київ : КНТ, 2007. 96 с.

\section{Анотація}

Берднік I. В., Головко М. Б. Функціональні особливості людини як складник оперативнорозшукової характеристики кримінальних правопорушень. - Стаття.

Стаття присвячена аналізу функціональних особливостей людини як складника оперативно-розшукової характеристики кримінальних правопорушень. Актуалізація дослідження зумовлена тим, що сполучною ланкою комплексу ознак оперативно-розшукової характеристики певного виду кримінальних правопорушень виступає агентурно-оперативний складник. При цьому науковці-дослідники у галузі кримінального права, кримінології, криміналістики залишають поза увагою факт застосування негласних форм і методів, які здебільшого використовуються у процесі оперативно-розшукової діяльності, а тому окремі елементи кримінального правопорушення саме з позиції застосування вказаних форм і методів вони не розглядають. Усунути цю прогалину покликана оперативно-розшукова характеристика кримінальних правопорушень, складовим елементом якої повинна бути інформація оперативно-розшукового характеру.

Під час дослідження функціональних особливостей людини як складника оперативно-розшукової характеристики кримінальних правопорушень зроблені такі висновки: 1) дослідження й вивчення навичок і функціональних особливостей людини служить основою для висунення версій про особу, яка вчинила кримінальне правопорушення або іншим чином причетна до його вчинення, що дозволить істотно звузити коло розшуку осіб або об'єднати в одне провадження кримінальні провадження про злочини, що мають ознаки серійності; 2) під час формування висновку щодо причетності особи до вчинення кримінального правопорушення на підставі дослідження її навичок та функціональних особливостей має враховуватися сукупність інформації, отриманої під час комплексного проведення оперативно-розшукових заходів, складання психологічного портрета, перевірки за базами оперативних та криміналістичних обліків, провадження експертних досліджень.

Ключові слова: оперативно-розшукова діяльність, оперативно-розшукові заходи, функціональні особливості, навички, слідчі дії, кримінальні правопорушення. 


\section{Summary}

Berdnik I.V., Holovko M. B. Human functional features as a component of operative and investigation characteristics of criminal offenses. - Article.

The article is devoted to the analysis of functional features of the person as a component of operatively investigation characteristic of criminal offenses. The actualization of the study is because the connecting link of a set of features of operational and investigative characteristics of a particular type of criminal offenses is the intelligence and operational component.

In order to close this gap, the researchers proposed to determine the operational and investigative characteristics of criminal offenses, an integral element of which should be information of operational and investigative nature. The authors define the operational and investigative characteristics of criminal offenses as an information model consisting of a set of individual aspects of criminal law, forensic, criminological, psychological, victimological characteristics, taking into account the most effective planning and search measures to perform the tasks of operational and investigation activities specified by law.

As a result of the study, the following conclusions are made:

1) research of skills and functional features of the person is the basis for the advancement of versions about the person who has committed a criminal offense or combine in total proceeding criminal proceedings for crimes that have signs of serialization;

2) when forming a conclusion on a person's involvement in a criminal of fense due to the study of his skills and functional characteristics should take into account the set of information obtained in comprehensive operational and investigative measures, psychological portrait, verification of operational and forensic records, expert researches. This conclusion is subject to verification in the course of pre-trial investigation through investigative actions.

Key words: operative investigation activity, operative investigation measures, functional features, skills, investigative actions, criminal offenses. 